Sains Malaysiana 50(2)(2021): 301-313

http://dx.doi.org/10.17576/jsm-2021-5002-03

\title{
A Deep Marine Origin for the Tajau Sandstone Member of the Kudat Formation, Kudat Peninsula, Sabah: Evidence from Facies Analysis and Ichnology \\ (Asalan Laut Dalam bagi Ahli Batu Pasir Tajau dalam Formasi Kudat, Semenanjung Kudat, Sabah: Bukti daripada Analisis Fasies dan Iknologi)
}

Hafzan Eva Mansor*, Meor Hakif Amir Hassan \& JunAidi Asis

\begin{abstract}
There have been many disagreements regarding the depositional environment of the Oligocene Tajau Sandstone Member of the Kudat Formation, Northern Sabah. We present here, the first detailed sedimentary facies analysis for the Tajau Sandstone Member, exposed on the Kudat Peninsula. The identified facies are interpreted as the deposits of subaqueous sediment density flows, which are common processes in deep marine depositional settings. These include debrites, hyperconcentrated density flow deposits, and turbidites. Several of the turbidite facies display evidence for hydraulic jumps, which are also common processes in deepwater settings and probably indicate changes in slope topography or loss of flow confinement. Trace fossils characteristic of the Nereites ichnofacies are also diagnostic of a deep marine depositional environment. Facies previously identified by previous workers as hummocky crossstratification in the Tajau Sandstone Member, which was used to support a shallow marine interpretation, is better interpreted as supercritical antidunes developed in high density turbidites, based on the coarse-grained texture, spaced layering and association with other subaqeuoues density flow deposits.
\end{abstract}

Keywords: Deep water facies; Tajau Sandstone Member; Kudat Formation

\section{ABSTRAK}

Terdapat banyak perselisihan pandangan mengenai persekitaran pengenapan ahli Batu Pasir Tajau, Formasi Kudat, di utara Sabah, yang berumur Oligosen. Di sini, kami membentangkan analisis fasies sedimen terperinci yang pertama untuk Ahli Batu Pasir Tajau, yang tersingkap di Semenanjung Kudat. Fasies yang dikenal pasti ditafsirkan sebagai enapan aliran ketumpatan sedimen bawah air, yang merupakan proses yang biasa berlaku dalam persekitaran laut dalam. Ini termasuk enapan debrit, aliran tumpat hiperkepadatan dan turbidit. Beberapa fasies turbidit menunjukkan bukti berlakunya proses lonjakan hidraulik yang merupakan proses yang biasa berlaku di sekitaran laut dalam dan mungkin menandakan perubahan topografi cerun atau kehilangan kekangan aliran. Kehadiran fosil surih daripada iknofasies Nereites juga adalah penentu untuk persekitaran laut dalam. Fasies dalam Ahli Batu Pasir Tajau yang sebelum ini dikenal pasti oleh penyelidik terdahulu sebagai perlapisan silang membusut dan digunakan untuk menyokong tafsiran pemendapan di sekitaran marin cetek, lebih sesuai ditafsirkan sebagai antigumuk supergenting yang terbentuk dalam turbidit berketumpatan tinggi. Ini berdasarkan teksturnya yang berbutir kasar, kehadiran pelapisan berjarak dan asosiasinya dengan enapan aliran ketumpatan bawah air yang lain.

Kata kunci: Ahli Batu Pasir Tajau; fasies laut dalam; Formasi Kudat

\section{INTRODUCTION}

There is significant disagreement regarding the depositional setting of the Oligocene Tajau Sandstone Member of the Kudat Formation in Sabah, with interpretations ranging from shallow to deep marine
(Ahmad et al. 2017; Frank 1981; Hall 2013; Hazebroek \& Tan 1993; Junaidi et al. 2017; Liechti et al. 1960; Nursyazwani et al. 2017; Samira et al. 2018; Sanudin et al. 2017; Stephens 1956; Suggate \& Hall 2013; Tongkul 2006, 1994, 1991; van Hattum et al. 2013). This study presented 
a limited facies analysis, with interpretations based on large-scale stratigraphic patterns, using data logged at 1:50 - 1:100 scale. Here, we present a more detailed, bed-scale facies analysis of the Tajau Sandstone Member exposed in Kudat Peninsula, Sabah, together with ichnological data.

The objectives of this study were to conduct a facies analysis of the Oligocene Tajau Sandstone Member, Kudat Formation, in Northern Sabah in order to interpret the processes that deposited the facies and determine the general depositional setting based on integrated facies analysis and ichnology.

\section{MATERIALS AND METHODS}

\section{GEOLOGICAL SETTING AND METHODS}

Due to the complex geological history of the Kudat Peninsula, several stratigraphic schemes have been constructed for the region (Ahmad et al. 2017; Clement \& Keij 1958; Liechti et al. 1960; Lim 1986; Lim \& Heng 1985; Shariff et al. 1994; Stephens 1956; Tongkul 2006). The oldest rock units in Kudat Peninsula is radiolarian chert dated as Barremian to Aptian (Basir \& Sanudin 1988; Basir et al. 1985). Other rock units exposed in the Kudat Peninsula are mélange, Kudat Formation, and Quaternary Alluvium. The most widely accepted stratigraphic scheme for the Kudat Peninsula is by Clement and Keij (1958) because the authors subdivided the Kudat Formation into six members (in stratigraphically ascending order, and from north to south; i.e. Tajau Sandstone, Sikuati, Garau Red Shales, Gomantong, Sirar, and Dudar). The subdivision into members are widely accepted as it provides a basic guideline to identify the Kudat Formation in the field. However, the age of each member is still unclear.

Tertiary siliciclastics of Northern Sabah unconformably overly Cretaceous ophiolitic rocks of the Chert-Spillite Formation and associated mafic and ultramafic bodies, interpreted as older oceanic crust (Hutchison 1996; Leong 1999; Rangin et al. 1990). The oldest of these Tertiary strata are the Crocker and Kudat formations. The Middle Eocene to Late Oligocene Crocker Formation is characterized by interbedded sandstones and mudstone interpreted as deep marine submarine fan deposits forming part of an accretionary complex (Ahmad et al. 2017; Crevello et al. 2008; Jackson et al. 2009; Rangin et al. 1990; van Hattum et al. 2013). The Crocker Formation laterally and vertically grades into the Oligocene to Early Miocene Kudat Formation (Frank 1981; Leong 1999; Lim 1986). Clement and Keij (1958) divided the rocks of the Kudat Formation into 6 Members, i.e. the Tajau Sandstone, Sikuati, Garau Red Shales, Gomantong, Sirar and Dudar, in stratigraphically younging order.

This paper focuses on the Oligocene Tajau Sandstone Member exposed on the Kudat Peninsula. The Tajau Sandstone Member is estimated to be about 6 $\mathrm{km}$ thick and comprises of thick-bedded, coarse grained to gravelly, micaceous, calcareous and feldspathic sandstones, with minor interbedded limestone, marls, and shales (Liechti et al. 1960). The age of the Tajau Sandstone Member remains a controversial subject, due to the presence of reworked Eocene foraminifera (Clement \& Keij 1958; Stephens 1956). The age has been recently revised to Late Oligocene to Early Miocene age, and the presence of Miogypsinella ubaghsi (Hock 1936) indicates a lowermost Early Miocene (23.0-20.4 Ma) or Early Aquitanian-Early Te5 (BouDagher-Fadel 2011; Suggate \& Hall 2013). Lunt and Madon (2017), in their review on the biostratigraphy in Kudat, also support a Late Oligocene age for the Tajau Sandstone Member.

The presence of foraminifera such as Amphistegina, Cycloclypeus, and Operculina are indicative of an outer neritic depositional environment; and Glomospira and Heterostegina indicate bathyal and inner neritic to nearshore, respectively (Lunt 2013). Detrital garnet composition analysis (Suggate \& Hall 2013) and heavy mineral contents and $\mathrm{U}-\mathrm{Pb}$ zircon age determination (van Hattum et al. 2013) suggest that sandstones of the Tajau Sandstone Member were potentially derived from a nearby high-grade metamorphic-acid plutonic source, possibly from the Palawan block of Philippines (originally part of South China) in the north.

\section{METHODS}

Sedimentary logging of 37 sections was conducted at 21 localities (see Figures 1 and 2 for the stratigraphy of the Kudat Peninsula), with a total logged thickness of $2171.58 \mathrm{~m}$. Facies of the Tajau Sandstone Member were described and classified based on their lithology, textural characteristics, sedimentary structures, and trace fossil composition. Thin sections of sandstones for petrographic analysis were prepared using rock-cutting facilities at the Universiti Malaysia Sabah (UMS). 




FIGURE 1. Geological map of the Kudat Peninsula, Northern Sabah, showing the location of logged sections, and Stratigraphy of the Kudat Peninsula

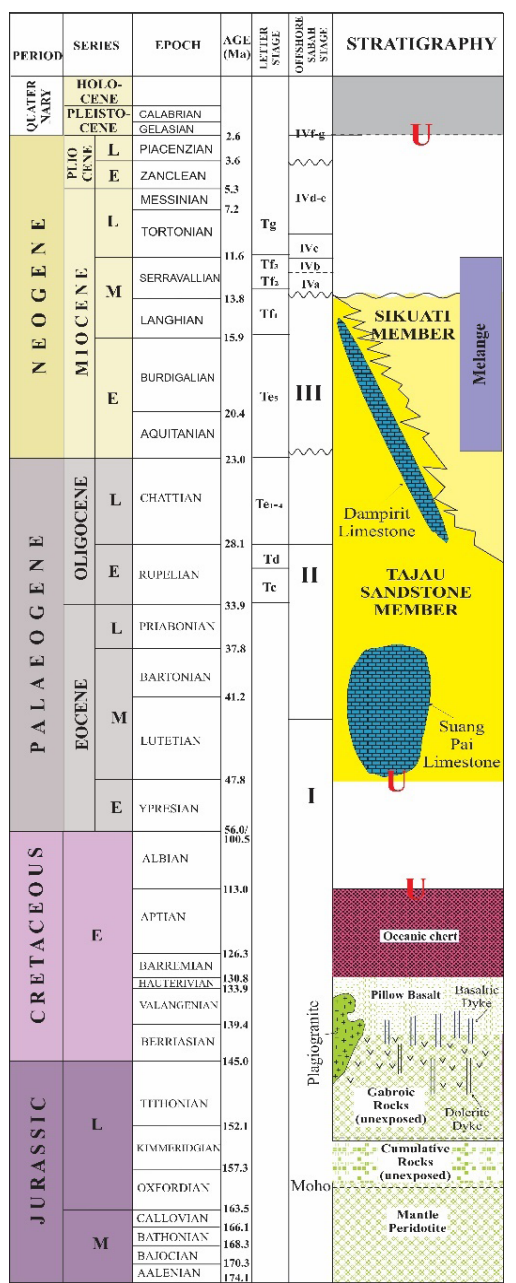

FIGURE 2. Stratigraphy of the Kudat Peninsula 


\section{RESULTS}

FACIES ANALYSIS OF THE TAJAU SANDSTONE MEMBER

Twelve facies are identified in the Tajau Sandstone Member, as summarized in Figure 3 and photographs in
Figures 5 and 6 . The identified facies are also represented in selected sedimentary logs as illustrated in Figure 4 and described herewith:

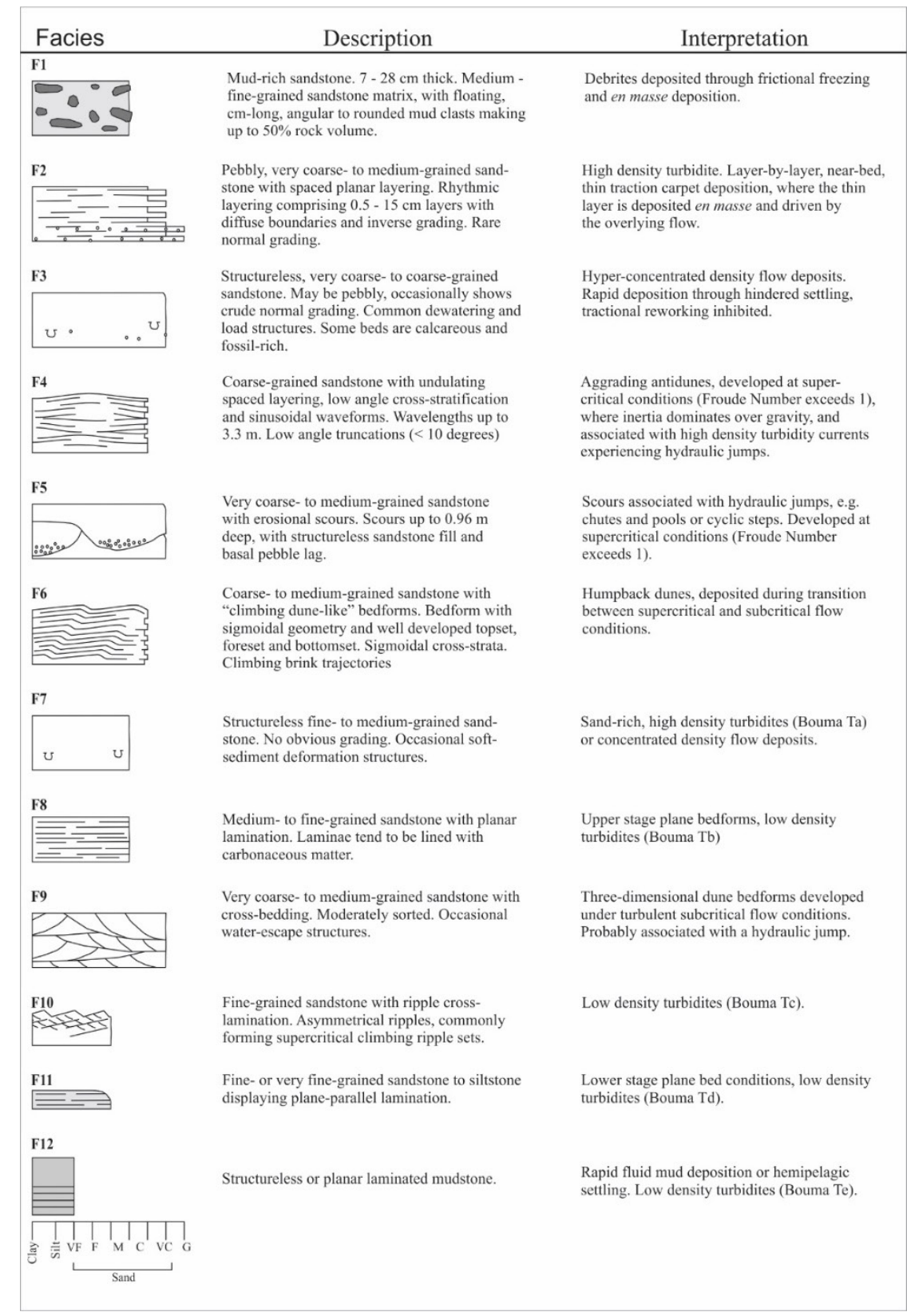

FIGURE 3. Summary of twelve identified facies in the Tajau Sandstone Member of Kudat Peninsula, Northern Sabah, and their interpreted depositional processes 


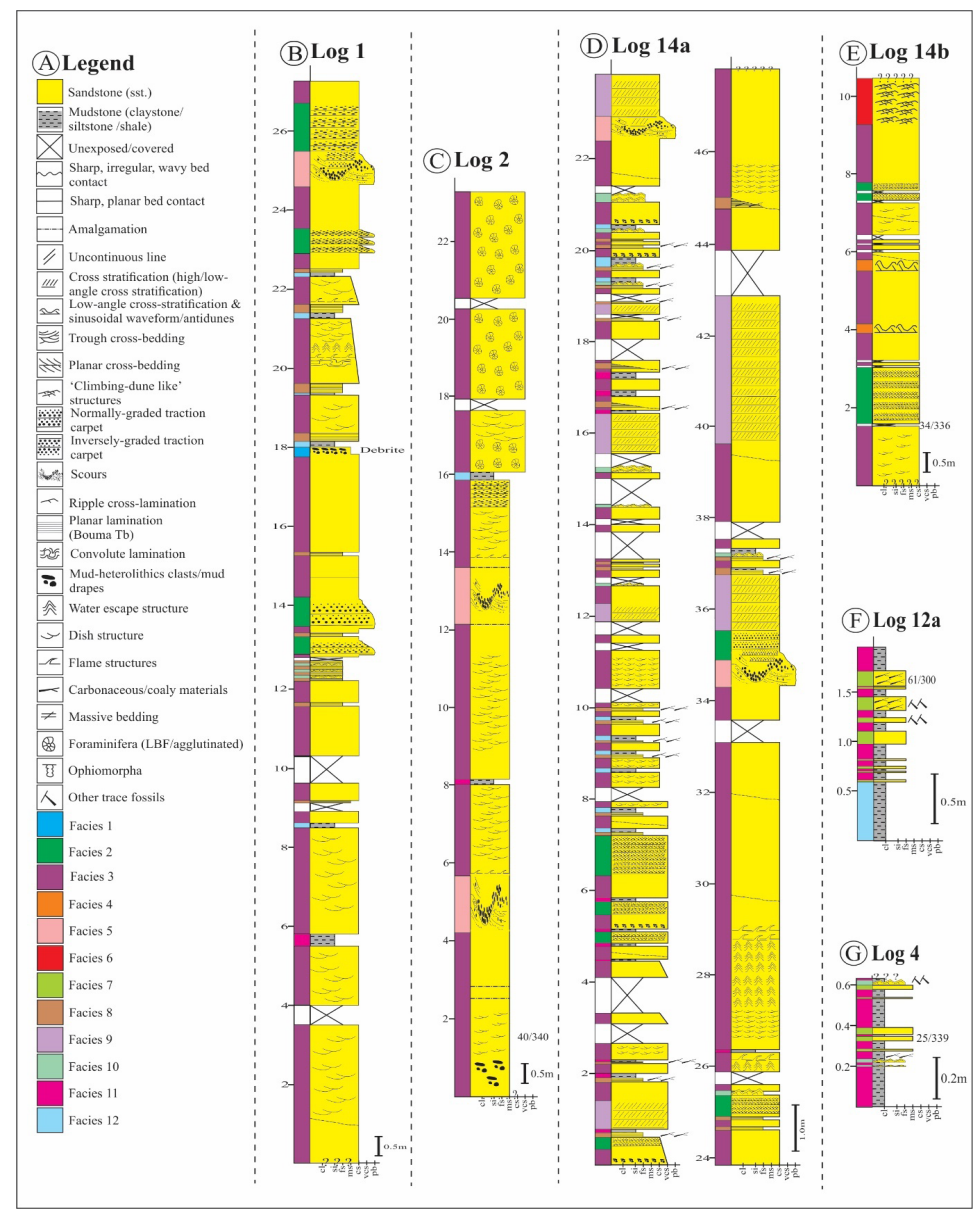

FIGURE 4. Selected sedimentary logs of the Tajau Sandstone Member in the Kudat Peninsula, Northern Sabah, showing the distribution of facies
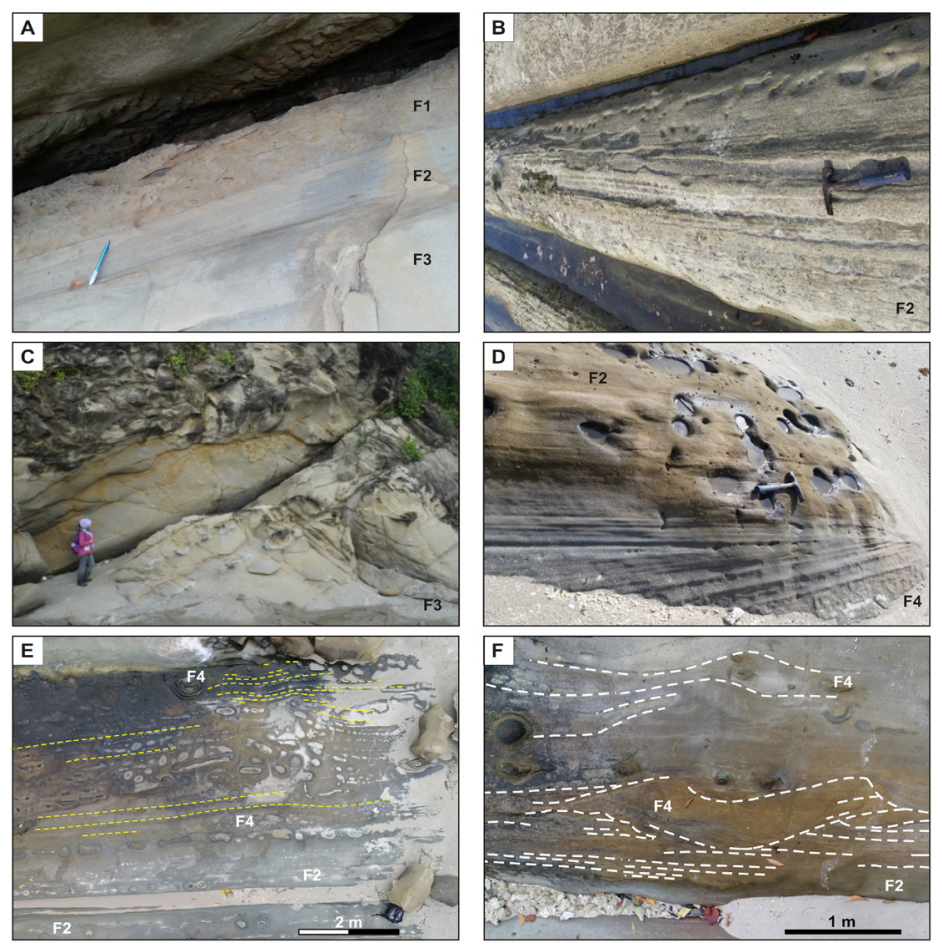

FIGURE 5. Selected facies of the Tajau Sandstone Member exposed on the Kudat Peninsula, Northern Sabah. (A) Thin debrite (F1) overlying stepped planar layered sandstone of F2, (B) Stepped planar layering in sandstone of F2, (C) Thick structureless sandstone of F3, (D) Low angle cross-stratification of stepped layers in F4, (E) Close vertical association between sinusoidal antidunes of F4 and spaced planar layering of F2, and (F) Sinusoidal antidunes of F4. Refer to Figure 2 for facies details 

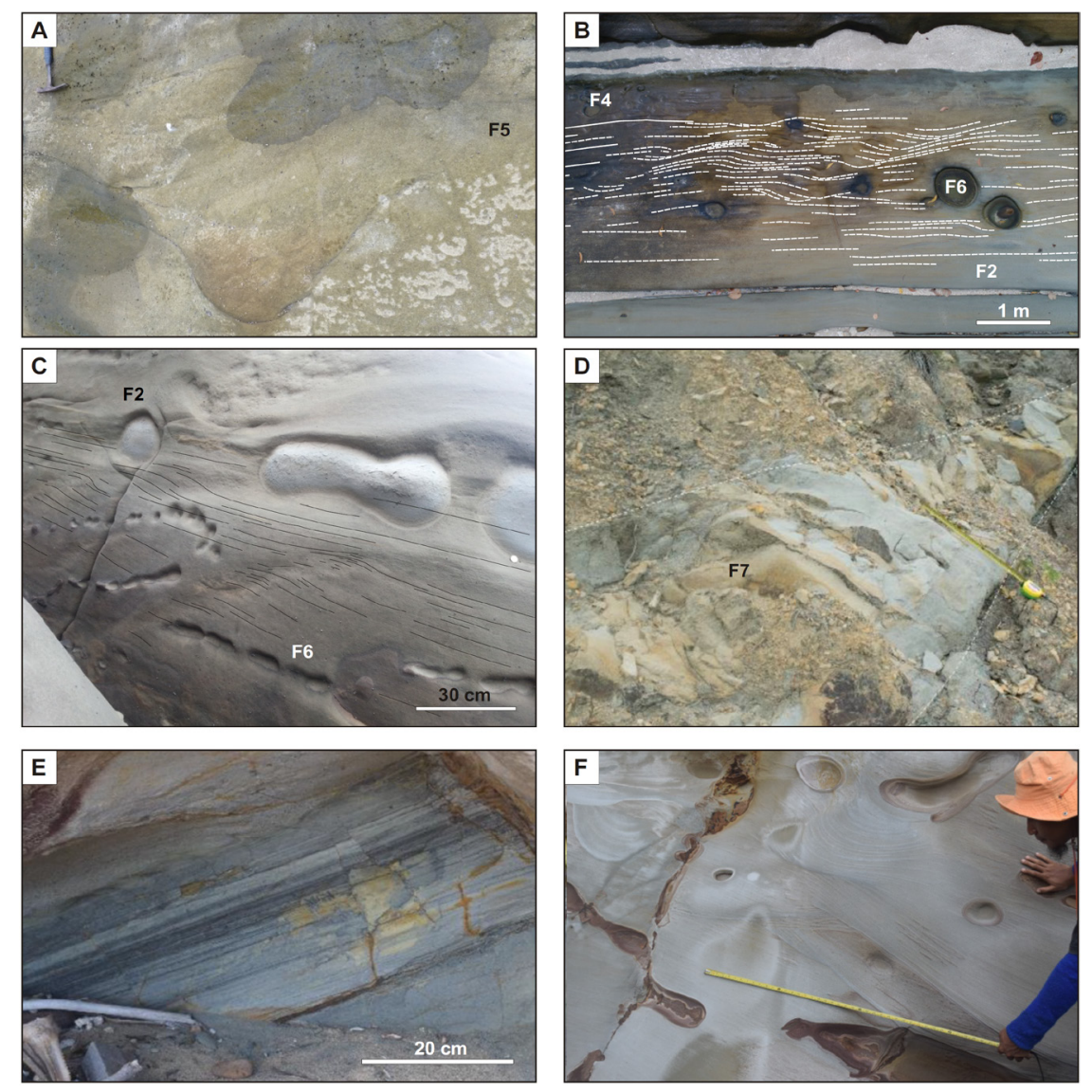

FIGURE 6. Selected facies of the Tajau Sandstone Member exposed on the Kudat Peninsula, Northern Sabah. (A) Scours filled with pebble lags and structureless sandstone of F5, (B, C) Humpback dunes with sigmoidal cross-stratification and climbing brink trajectories, F6, (D) Structureless sandstone of F7, (E) Planar laminated sandstone with carbonaceous matter lining, F8, and (F) Trough cross-bedded sandstone of F9. Refer to Figure 3 for facies details

\section{FACIES 1 (F1): MUD CLAST RICH SANDSTONE}

Description: F1 is represented by $7-28 \mathrm{~cm}$ thick, ungraded, matrix-supported conglomerates, with a medium- to fine-grained sandstone matrix and chaotically-arranged mud clasts making up $35-50 \%$ of the rock volume. The sandstone is muddy, medium-to fine grained, structureless (i.e. displaying an absence of primary sedimentary structures), ungraded, poorly-sorted, and light to dark grey coloured. The mud clasts are elongated and angular to rounded, and chaotically oriented.

Interpretation: $\mathrm{F} 1$ is interpreted as debrites based on the ungraded bedding, with abundant, chaotically oriented clasts floating in a sandstone matrix (Lowe 1982; Mutti et al. 2003). Debrites are deposited from frictional freezing and abrupt en masse deposition from a debris flow (Mulder \& Alexander 2001).
FACIES 2 (F2): PEBBLY, VERY COARSE- TO MEDIUMGRAINED SANDSTONE WITH PLANAR LAYERING

Description: F2 is characterized by sandstone with internal planar layering. The layering can be either in the form of: 3 to $8 \mathrm{~cm}$ thick, alternating coarse-grained and pebbly sandstone layers. The boundaries between layers are diffuse; 0.5 to $1.5 \mathrm{~cm}$ thick, inverse graded and occasional normal graded sandstone (i.e. spaced planar layering). The layering is typically parallel to bedding, although some examples display gently inclined layering, or; (3) less than $1 \mathrm{~mm}$ thick, with no vertical grain size variation. There are typically no major grain size differences between bands. However, in some rare cases, inverse grading is observed. Bioturbation is absent in these facies.

Interpretation: F2 is interpreted as traction carpet deposition from a high-density turbidity current, based 
on the presence of spaced layering in very coarse- to finegrained sandstone (Hiscott 1994; Lowe 1982; Sohn 1997). Traction carpets form through near-bed, en masse settling of thin layers of sand, driven by an overlying flow (Hiscott 1994; Kuenen 1966; Talling et al. 2012). They are typical of high-density turbidites (Cartigny et al. 2013; Postma et al. 1988; Sohn 1997). However, the coarse-grained texture of $\mathrm{F} 3$ excludes a $\mathrm{Tb}$ Bouma division interpretation. The inverse-graded layers in F2 were probably due to downward percolation of finer grains through the gaps between coarser grains (Legros 2002).

\section{FACIES 3 (F3): STRUCTURELESS, VERY COARSE- TO COARSE-GRAINED SANDSTONE}

Description: Facies 3 is characterized by structureless or bioturbated, very poorly-sorted pebbly to very coarsegrained sandstone. F3 tends to form amalgamated stacks of tabular beds up to $25 \mathrm{~m}$ thick. F3 is structureless or displays poorly developed normal grading. Dish structures, ball-and-pillow structures and flames structures are common. The granules and pebbles in this subfacies are sub- to well-rounded, with an average size of 3-5 $\mathrm{mm}$, with occasional grains up to $12 \mathrm{~mm}$ in diameter. Some examples of F3 are calcareous and rich in fossils, including foraminifera (e.g. Heterostegina borneensis van der Vlerk, Heterostegina sp., Lepidocyclina (Eulepidina) sp., Lepidocyclina (Nephrolepidina) sp., Lepidocyclina sp., Operculina sp., Amphistegina sp.) and fragments of algae, coral and gastropods.

Interpretation: F3 is interpreted as the deposits of non-cohesive, hyper-concentrated density flows, based on the coarse-grained texture and internally structureless framework (Alexander 2001; Mulder \& Mutti et al 2003; Tinterri et al. 2003). The structureless, ungraded deposits may have been produced by rapid, hindered settling, which inhibited tractional reworking (Lowe 1982) or by en masse deposition (Talling et al. 2002).

\section{FACIES 4 (F4): COARSE-GRAINED SANDSTONE WITH UNDULATING LAYERING AND LOW ANGLE CROSS- STRATIFICATION}

Description: F4 is characterized by coarse-grained sandstone displaying internal spaced layering with sinusoidal wave-like profiles. The waveforms display symmetrical, rounded crests and have wavelengths of up to $3.3 \mathrm{~m}$. Low angle cross-stratification (less than $10^{\circ}$ ) of spaced layers is also observed. Trough-shaped scours are common in F4, where they truncate spaced layers of underlying and laterally associated bedforms. F4 grades laterally and upwards into spaced layering of F2.

Interpretation: The bedforms of F4 are interpreted as antidunes, based on the undulating, symmetrical, sinusoidal profile, and associated undulating to low angle cross-stratified, internal spaced layering (Cartigny et al. 2014; Lang \& Winsemann 2013; Middleton 1965; Postma \& Kleverlaan 2018; Yagishita 1994). The development of antidunes reflects supercritical flow conditions under high rates of aggradation (Alexander et al. 2001; Cartigny et al. 2014; Lang \& Winsemann 2013). The spaced layering making up the internal stratification indicates traction carpet deposition, which is characteristic high density turbidites (Postma et al. 1988; Sohn 1997).

\section{FACIES 5 (F5): VERY COARSE- TO MEDIUM-GRAINED SANDSTONE WITH EROSIONAL SCOURS}

Description: Facies 5 is characterized by amalgamated, pebbly, very coarse- to medium-grained sandstones displaying abundant erosional features in the form of internal scours and fills. The scours have reliefs of up to $0.9 \mathrm{~m}$ and widths of up to $1.2 \mathrm{~m}$. The scours are filled by a basal gravel lag, which is overlain by structureless sandstone. The basal scour surfaces cut into underlying beds and are emphasized by amalgamation, with sharp and undulating profiles. Bioturbation is absent in these facies. Interpretation: F5 is interpreted as hyperconcentrated density flow deposits or high density turbidites with hydraulic jump-induced erosion, based on the structureless coarse grained sandstone and abundance of internal scours (Mulder \& Alexander 2001; Mutti et al. 2003). Turbidity currents can experience hydraulic jumps (i.e. transformation from supercritical to subcritical flow conditions) due to flow expansion associated with a slope change or loss of flow confinement. Flow turbulence is locally increased, resulting in scouring and partial deposition of its load (Ito et al. 2014; Komar 1971; Kostic \& Parker 2006; Lowe 1982; Taki \& Parker 2005).

FACIES 6 (F6): COARSE- TO MEDIUM-GRAINED SANDSTONE WITH 'CLIMBING DUNE-LIKE' BEDFORMS

Description: F6 is characterized by 1 to $1.5 \mathrm{~m}$ thick units of medium- to coarse-grained sandstone displaying low angle, sigmoidal cross-stratification of spaced planar layering. Stacked spaced layering forms 0.4 to $1.4 \mathrm{~m}$ long bedforms with well-developed topset, forest and bottomset elements. Sigmoidal cross-stratification is restricted to the foreset area. The cross-stratification displays climbing brink trajectories, with climbing angles between $20^{\circ}$ and $39^{\circ}$. The low angle foresets are formed by parallel layers of become divergent (i.e. thickening and becoming gentle in angle further downdip). The climbing bedforms of Facies 6 have heights and wavelengths exceeding 0.075 and $0.020 \mathrm{~m}$, respectively. F6 grades laterally and vertically into F6 and F5. 
Interpretation: F6 is interpreted as high density turbidites with evidence of transitions between subcritical and supercritical flow conditions, based on the presence of spaced layering associated with humpback dunes. The bedforms with low angle, sigmoidal cross-stratification are identified as humpback dunes (Chakraborty \& Bose 1992; Fielding 2006; Lang \& Winsemann 2013), which are known to form during the transition between supercritical and subcritical flow conditions (Saunderson \& Lockett 1983). The spaced layering represents traction carpets which are typical of high density turbidites. The close association of F6 and antidunes of F4 is also consistent with downflow and temporal fluctuations between subcritical and supercritical conditions (Lang \& Winsemann 2013).
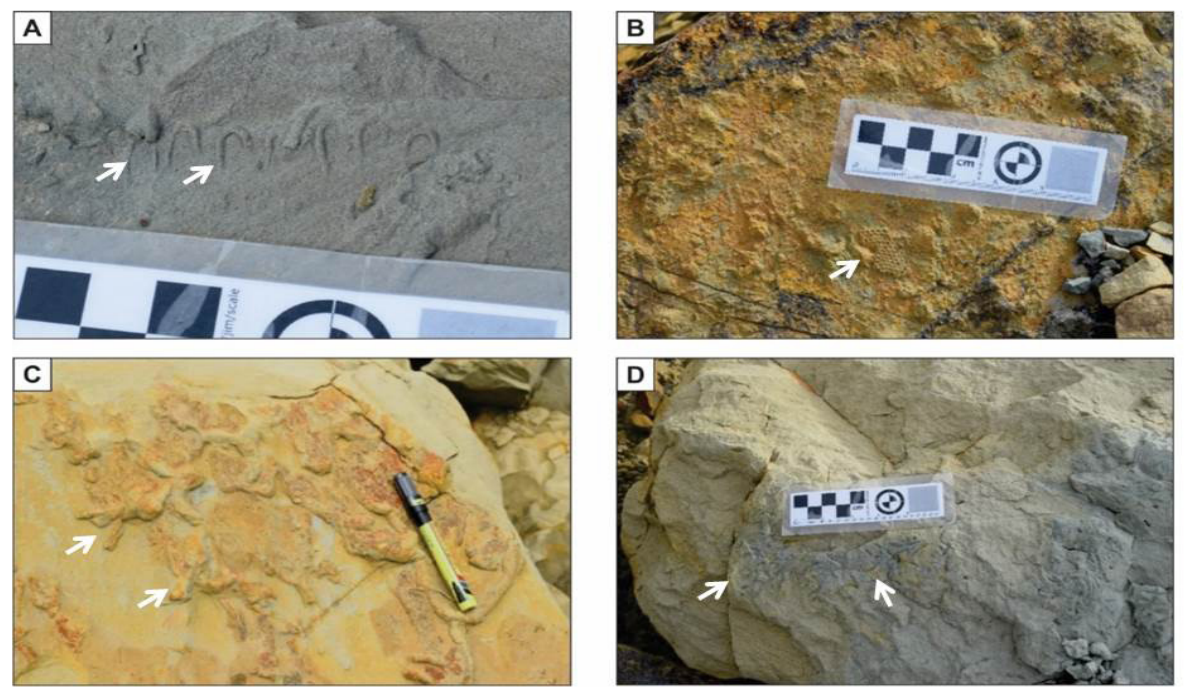

FIGURE 7. Trace fossils characteristic of the Nereites ichnofacies, observed along the base of F7 structureless sandstone, Tajau Sandstone Member, Kudat Peninsula, Northern Sabah. (A) Belorhaphe (B) Paleodictyon; (C and D) Cosmorhaphe

Interpretation: F7 is equivalent to the classic Ta division of Bouma (1962) and is interpreted as either high density turbidites (Kneller \& Branney 1995; Lowe 1982; Talling et al. 2012) or rapid fall-out from concentrated density flow deposits (Lowe 1982; Mulder \& Alexander 2001; Talling et al. 2012).

\section{FACIES 8 (F8): FINE-GRAINED SANDSTONE WITH PLANAR LAMINATION}

Description: F8 forms intervals of fine- to medium-grained sandstone displaying rhythmic planar lamination.

\section{FACIES 7 (F7): STRUCTURELESS FINE- TO MEDIUM- GRAINED SANDSTONE}

Description: F7 is characterized by 0.3 to $3.5 \mathrm{~m}$ thick beds of sharp-based, structureless, fine- to mediumgrained sandstone. There is no obvious grading and the only sedimentary structures observed are occasional soft-sediment deformation. This facies displays a sharp upper and lower contact. The sandstone also contains mud clasts/pebbles and very minor elongate coal pebbles/ carbonaceous matters, scattered in the upper part of this facies. Nereites inchnofacies (e.g. Paleodictyon and Cosmorhaphe) are also observed in this facies (Figure 7). 


\section{FACIES 9 (F9): VERY COARSE- TO MEDIUM-GRAINED SANDSTONE WITH CROSS-BEDDING}

Description: F9 comprises very coarse- to medium-grained sandstone with trough cross-bedding. The cross-beds range between 0.6 and $3.5 \mathrm{~m}$ in thickness. The cross-beds range between 0.6 and $3.5 \mathrm{~m}$ in thickness, with tangential foresets reaching angles of up to 25 degrees. Individual troughs exhibit widths and maximum depths in the range of $<40$ to $>92 \mathrm{~cm}$, and 5 to $95 \mathrm{~cm}$, respectively. F9 occurs in close association with the F4.

Interpretation: F9 represents the deposits of threedimensional dunes developed under turbulent subcritical flow conditions, based on the presence of trough crossbedding (Ashley 1990). The close association with other turbiditic facies suggests deposition or at least evolution from gravity flows. Mutti et al. (2003) relate the presence of dune bedforms in turbidites as indicative of a hydraulic jump.

FACIES 10 (F10): RIPPLE CROSS-LAMINATED SANDSTONE

Description: F10 is mainly fine-grained sandstone intervals displaying asymmetrical, climbing ripple crosslamination sets with occasional single ripple sets. The ripples are 1 to $3 \mathrm{~cm}$ high and $c a .10 \mathrm{~cm}$ long. The climbing ripples have an angle of climb between 15 and $45^{\circ}$. The base of F10 is generally sharp and straight, while the upper contact with overlying facies is gradational. F10 also contain soft-sediment deformation in the form of convolute lamination. Moderate bioturbation $(\mathrm{BI}=3)$ is observed in beds of F10, including the Thalassinoides and Planolites.

Interpretation: F10 is equivalent to the Tc division of Bouma (1962) and is interpreted as low density turbidites, based on the close association of the ripples with other turbiditic facies. Deposition of F10 was from fully turbulent dilute suspension, with relatively low rates of sedimentation (Baas 1994; Southard 1991). However, deposition was rapid enough to form climbing trajectories (Jobe et al. 2012).

\section{FACIES 11 (F11): LAMINATED VERY FINE-GRAINED SANDSTONE OR SILTSTONE}

Description: F11 is characterized by $\mathrm{cm}$-thick units of fine- to very fine-grained sandstone or coarse siltstone, displaying plane-parallel lamination. The laminae are commonly light to greyish in colour. In some cases, F11 contains intervals with convolute lamination. These facies are rare in the Tajau Sandstone Member.

Interpretation: F11 is equivalent to the Td division of Bouma (1962) and has been interpreted as dilute, low density turbidites, deposited under fully turbulent flow and low sediment concentrations (Talling et al. 2012).
FACIES 12 (F12): MUDSTONE

Description: F12 is characterized by up to $20 \mathrm{~cm}$ thick, structureless or planar laminated mudstone. It is generally difficult to determine whether the mudstone of this facies is graded or ungraded. The thin mudstone commonly has a sharp or gradual contact with overlying and underlying beds.

Interpretation: F12 is interpreted as mainly hemipelagic deposits (Lowe 1982). Structureless mudstone may also represent rapid fluid mud deposition (Talling et al. 2012).

\section{ICHNOLOGICAL ANALYSIS OF THE TAJAU SANDSTONE MEMBER}

Bioturbation is observed in three facies of the Tajau Sandstone Member, i.e. F3, F7, and F10. Structureless sandstones of F3 contain identifiable trace fossils such as Planolites and Ophiomorpha. Trace fossils are also common in the finer grained structureless sandstones of F7 and include Ophiomorpha, Chondrites, Cosmorhaphe, Palaeodictyon, Scolicia, and Belorhaphe. Moderate bioturbation in rippled cross-laminated sandstones of F10, including trace fossils such as Thalassinoides and Planolites.

The trace fossil assemblages observed in the Tajau Sandstone Member comprise well established marine ichnotaxa (e.g. MacEachern et al. 2010). Vertical Ophiomorpha associated with F3 is characteristic of the Skolithos ichnofacies, which is typically developed in well sorted, shifting sand substrates. This is consistent with the gravity flow interpretation for F3 and F7. The Ophiomorpha observed in the Tajau Sandstone may also represent elements of the Nereites ichnofacies (Uchman 2009). The assemblage containing Planolites and Thalassinoides is consistent with the Cruziana ichnofacies, which is characteristic of marine softground substrates. The presence of Palaeodictyon in F7 is important, and its association with Chondrites and Scolicia is representative of the Nereites ichnofacies. The Nereites ichnofacies is restricted to modern-day deep marine settings, and ancient turbidites and abyssal plain deposits (MacEachern et al. 2010, 2007).

\section{DISCUSSION}

The majority of the facies identified in the Tajau Sandstone Member display characteristics which are consistent with deposits formed by underwater flows driven by excess density, which was produced by sediments, i.e. subaqueous sedimentary density flows (Mulder \& Alexander 2001). This includes facies interpreted as debrites (F1), poorly cohesive debrites to hyperconcentrated density flows (F3) and turbidites 
(including classical divisions of the Bouma sequence, e.g. F7, F8, F10, F11, F12 and high density turbidites, i.e. F2). Several other facies identified in the Tajau Sandstone Member display characteristics which are consistent with deposition associated with hydraulic jumps, including supercritical antidunes and scours (F4, F5), trans-critical bedforms (F6) and subcritical bedforms (F9). The gradual transitions between these facies reflect downflow and temporal fluctuations between subcritical and supercritical conditions (Lang \& Winsemann 2013). The internal stratification of these facies are consistent with traction carpets, and indicate deposition by high density turbidity currents. Similar bedforms have been observed in other subaqueous sedimentary density flow deposits associated with submarine fans (Cartigny et al. 2011; Hand et al. 1972; Kostic \& Parker 2006; Postma et al. 2009; Walker 1967). Hydraulic jumps can develop in submarine fan settings due to abrupt deceleration and flow expansion associated with an abrupt change in degree of confinement, such as observed at channel-lobe transitions, or slope gradient (García \& Parker 1993; Hofstra et al. 2015; Komar 1971; Macdonald et al. 2011; Normark \& Piper 1991).

Initially, the presence of abundant large benthic foraminifera and associated shallow marine fossils in F3 appears to be inconsistent with a deep marine submarine fan depositional model. However, the reworked nature of the fossils, with evidence of breakage and dissolution, and mixed ages of the foraminifera, indicate that these fossils have been reworked and transported from a shallower setting. The most conclusive evidence for a deep marine depositional setting comes from ichnology, as the Nereites ichnofacies is only known from modern-day deep marine settings and are associated with turbidites in numerous examples in the rock record (MacEachern et al. 2010, 2007; Rona et al. 2009; Seilacher 2007).

A deep marine setting for the Tajau Sandstone Member has been previously proposed by several authors (Ahmad et al. 2017), but none of these works provided a facies analysis to support their interpretations. Sanudin et al. (2017) provided an alternate interpretation, where the Tajau Sandstone Member represents shallow marine deposits, based on the identification of hummocky (HCS) and swaley cross-stratified (SCS) sandstone, which are storm-generated deposits requiring shallow waters above wave base to develop (Dumas \& Arnott 2006; Harms et al. 1975). However, the coarse-grained texture of their storm beds is not consistent with HCS and SCS, which only develop in very fine- to fine-grained sandstones (Cummings et al. 2009; Dumas et al. 2005). The coarsegrained, undulating and planar spaced layering, which are closely associated with other density flow deposits and hydraulic jump-associated bedforms, are better interpreted as traction carpets associated with high density turbidites.

\section{CONCLUSION}

A detailed facies analysis of the Oligocene Tajau Sandstone Member, Kudat Formation in Kudat, Sabah, indicates the presence of 12 facies, of which 8 facies are interpreted as subaqueous sediment density flow deposits, including debrites (F1), poorly cohesive debrites or hyperconcentrated density flow deposits (F2) and turbidites (F3, F7, F8, F10, F11, F12). Four facies are interpreted as deposits associated with hydraulic jumps, including supercritical antidunes and scours (F4, F5), trans-critical humpback dunes (F6) and subcritical 3D dunes. Hydraulic jumps may have developed due to flow expansion possibly associated with a change in slope gradient of a change in flow confinement, which are common processes in deep marine submarine fans. Previously described hummocky cross-stratification in the Tajau Sandstone Member are better interpreted as antidunes due to the coarse-grained texture of the sandstone and stepped layering of the strata, which is again consistent with traction carpet deposition associated with high density turbidites. The presence of the Nereites inchnofacies confirms the deep marine setting of the Tajau Sandstone Member.

\section{ACKNOWLEDGEMENTS}

The bulk of the work presented here is part of Hafzan Eva's PhD project at the Department of Geology, University of Malaya. The research is supported by the Government of Malaysia Fundamental Research Grant (FRGS Project Number: FP056-2017A). We would also like to thank Prof. Dr. Che Aziz and Associate Prof. Dr. A Hadi A Rahman for reviewing this manuscript.

\section{REFERENCES}

Ahmad, R.R., Zainey, K., Junaidi, A., Nursyazwani, A.J., Abdul, J.M., Norazhar, I., Munif, K., Razali, C.K., Hisham, M. \& Tjia, H.D. 2017. Tectonostratigraphic terranes of Kudat Peninsula, Sabah. Bulletin of the Geological Society Malaysia 64: 123-139.

Alexander, J., Bridge, J.S., Cheel, R.J. \& Leclair, S.F. 2001. Bedforms and associated sedimentary structures formed under water flows over aggrading sand beds. Sedimentology 48(1): 133-152.

Ashley, G.M. 1990. Classification of large-scale subaqueous bedforms: A new look at an old problem. Journal of Sedimentary Petrology 60(1): 160-172.

Baas, J.H. 1994. A flume study on the development and equilibrium morphology of current ripples in fine sand. Sedimentology 41(2): 185-209.

Basir, J. \& Sanudin, T. 1988. Barremian Radiolaria from the Chert-Spilite Formation, Kudat, Sabah. Sains Malaysiana 17(1): 67-69.

Basir, J., Sanudin, T. \& Abdul, R.S. 1985. Lower Cretaceous Radiolaria from the Chert-Spilites Formation, Kudat, Sabah. Warta Geologi 11(4): 161-162. 
Bouma, A.H. 1962. Sedimentology of Some Flysch Deposits: A Graphic Approach to Facies Interpretation. Amsterdam: Elsevier. p. 168.

Cartigny, M.J.B., Ventra, D., Postma, G. \& van den Berg, J.H. 2014. Morphodynamics and sedimentary structures of bedforms under supercritical-flow conditions: New insights from flume experiments. Sedimentology 61(3): 712-748.

Cartigny, M.J.B., Eggenhuisen, J.T., Hansen, E.W.M. \& Postma, G. 2013. Concentration dependent flow stratification in experimental high-density turbidity currents and their relevance to turbidite facies models. Journal of Sedimentary Research 83(12): 1046-1064.

Cartigny, M.J.B., Postma, G., van den Berg, J.H. \& Mastbergen, D.R. 2011. A comparative study of sediment waves and cyclic steps based on geometries, internal structures and numerical modeling. Marine Geology 280(1-4): 40-56.

Chakraborty, C. \& Bose, P.K. 1992. Ripple/dune to upper stage plane bed transition: Some observations from the ancient record. Geological Journal 27(4): 349-359.

Clement, J.F. \& Keij, J. 1958. Geology of the Kudat Peninsula, North Borneo (Compilation) GR783. British Borneo: Royal Dutch Shell Group of Companies.

Crevello, P.D., Johnson, H.D., Tongkul, F. \& Wells, M.R. 2008. Mixed braided andleveed-channel turbidites, West Crocker Fan system, Northwest Borneo. In Atlas of Deep Water Outcrops (AAPG Studies in Geology). United States: American Association of Petroleum Geologists.

Cummings, D.I., Dumas, S. \& Dalrymple, R.W. 2009. Fine grained versus coarse-grained wave ripples generated experimentally under large-scale oscillatory flow. Journal of Sedimentary Research 79(2): 83-93.

Dumas, S. \& Arnott, R.W.C. 2006. Origin of hummocky and swaley cross-stratification - The controlling influence of unidirectional current strength and aggradation rate. Geology 34(12): 1073-1076.

Dumas, S., Arnott, R.W.C. \& Southard, J.B. 2005. Experiments on oscillatory-flow and combined-flow bed forms; implications for interpreting parts of the shallow-marine sedimentary record. Journal of Sedimentary Research 75(3): 501-513.

Fielding, C.R. 2006. Upper flow regime sheets, lenses and scour fills: extending the range of architectural elements for fluvial sediment bodies. Sedimentary Geology 190(1-4): 227-240.

Frank, P.L. 1981. Report No. 2021. The Onshore Geology of the Kudat Peninsula and Northern Islands, Sabah. Kuala Lumpur: Carigali-BP Sdn. Bhd.

García, M. \& Parker, G. 1993. Experiments on the entrainment of sediment into suspension by a dense bottom current. Journal of Geophysical Research 98(C3): 4793-4807.

Hall, R. 2013. Contraction and extension in northern Borneo driven by subduction rollback. Journal of Asian Earth Sciences 76: 399-411.

Hand, B.M., Middleton, G.V. \& Skipper, K. 1972. Antidune crossstratification in a turbidite sequence, Cloridorme Formation, Gaspé, Quebec. Sedimentology 18(1-2): 135-138.

Harms, J.C., Southard, J.B., Spearing, D.R. \& Walker, R.G. 1975. Depositional environments as interpreted from primary sedimentary structures and stratification sequences. In Society for Sedimentary Geology Course Notes. United States: Society for Sedimentary Geology.
Hazebroek, H.P. \& Tan, D. 1993. Tertiary tectonic evolution of the NW Sabah continental margin. Bulletin of the Geological Society Malaysia 33(27): 195-210.

Hiscott, R.N. 1994. Traction-carpet stratification in turbidites; fact or fiction. Journal of Sedimentary Research 64(2a): 204-208.

Hofstra, M., Hodgson, D., Peakall, J. \& Flint, S. 2015. Giant scour-fills in ancient channel-lobe transition zones: Formative processes and depositional architecture. Sedimentary Geology 329: 98-114.

Hutchison, C.S. 1996. The 'Rajang accretionary prism' and 'Lupar Line' problem of Borneo. In Tectonic Evolution of Southeast Asia. London: Geological Society. pp. 247-261.

Ito, M., Ishikawa, K. \& Nishida, N. 2014. Distinctive erosional and depositional structures formed at a canyon mouth: A lower Pleistocene deep-water succession in the Kazusa forearc basin on the Boso Peninsula, Japan. Sedimentology 61(7): 2042-2062.

Jackson, C.A.L., Zakaria, A.A., Johnson, H.D., Tongkul, F. \& Crevello, P.D. 2009. Sedimentology, stratigraphic occurrence and origin of linked debrites in the West Crocker Formation (Oligo-Miocene), Sabah, NW Borneo. Marine and Petroleum Geology 26(10): 1957-1973.

Jobe, Z.R., Lowe, D.R. \& Morris, W.R. 2012. Climbing-ripple successions in turbidite systems: Depositional environments, sedimentation rates and accumulation times. Sedimentology 59(3): 867-898.

Junaidi, A., Sanudin, T., Ahmad, R.R., Zainey, K. \& Tjia, H.D. 2017. Smaller benthic foraminifera analysis of Kudat Formation, Kudat, Sabah: Preliminary interpretation. Geological Behaviour (GBR) 1(1): 27-29.

Kneller, B. \& Branney, M.J. 1995. Sustained high density turbidite currents and the deposition of thick massive sands. Sedimentology 42(4): 607-616.

Kuenen, P.H.H. 1966. Experimental turbidite lamination in a circular flume. Journal of Geology 74(5): 523-545.

Komar, P.D. 1971. Hydraulic jumps in turbidity currents Geological Society of America Bulletin 82(6): 1477-1488.

Kostic, S. \& Parker, G. 2006. The response of turbidity currents to a canyon-fan transition: Internal hydraulic jumps and depositional signatures. Journal of Hydraulic Research 44(5): 631-653.

Lang, J. \& Winsemann, J. 2013. Lateral and vertical facies relationships of bedforms deposited by aggrading supercritical flows: From cyclic steps to humpback dunes. Sedimentary Geology 296: 36-54.

Legros, F. 2002. Can dispersive pressure cause inverse grading in grain flows? Journal of Sedimentary Research 73(2): 166-170.

Leong, K.M. 1999. Geological setting of Sabah. In The Petroleum Geology and Resources of Malaysia. Kuala Lumpur: Petroliam Nasional Berhad (PETRONAS). pp. 475-497.

Liechti, P., Roe, F.W. \& Haile, N.S. 1960. The geology of Sarawak, Brunei and Western Part of North Borneo. In Compiled from Work of the Royal Dutch Shell Group of Companies in the British Territories in Borneo and from Various Published Accounts. California: H.M. Stationery Office. p. 360.

Lim, P.S. 1986. Sabah Geological Map. Scale: 1: 50000. Kuala Lumpur: Geological Survey of Malaysia. 
Lim, P.S. \& Heng, Y.E. 1985. Geological Map of Sabah, 1:500,000. Kuala Lumpur: Geological Survey of Malaya.

Lowe, D.R. 1982. Sediment gravity flows: II. Depositional models with special reference to the deposits of high-density turbidity currents. Journal of Sedimentary Petrology 52(1): 279-297.

Lunt, P. 2013. Foraminiferal micropalaeontology in SE Asia. In Landmarks in Foraminiferal Micropalaeontology: History and Development. London: The Geological Society. London. pp. 193-206.

Lunt, P. \& Madon, M. 2017. Onshore to offshore correlation of northern Borneo; A regional perspective. Bulletin of the Geological Society of Malaysia 64: 101-122.

Macdonald, H.A., Peakall, J. \& Wignall, P.B. 2011. Sedimentation in deepsea lobe-elements: Implications for the origin of thickening-upward sequences. Journal of the Geological Society 168: 319-331.

MacEachern, J.A., Bann, K.L., Pemberton, S.G. \& Gingras, M.K. 2007. The ichnofacies paradigm: High-resolution palaeoenvironmental interpretation of the rock record. In Applied Ichnology, Society for Sedimentary Geology Special Publication. London: SEPM. pp. 49-85.

MacEachern, J.A., Pemberton, S.G., Gingras, M.K. \& Bann, K.L. 2010. Ichnology and facies models. In Facies Models 4. Canada: Geological Association of Canada. pp. 19-58.

Middleton, G.V. 1965. Antidune cross-bedding in a large flume. Journal of Sedimentary Petrology 35(4): 922-927.

Mulder, T. \& Alexander, J. 2001. The physical character of subaqueous sedimentary density flows and their deposits. Sedimentology 48(2): 269-299.

Mutti, E., Tinterri, R., Benevelli, G., DiBiase, D. \& Cavanna, G. 2003. Deltaic, mixed and turbidite sedimentation of ancient foreland basins. Marine and Petroleum Geology 20(6-8): 733-755.

Normark, W.R. \& Piper, D.J. 1991. Initiation processes and flow evolution of turbidity currents: Implications for the depositional record. In From Shoreline to Abyss: Contributions in Marine Geology in Honor of Francis Parker Shepard. United States: SEPM. pp. 207-230.

Nursyazwani, A.J. \& Abdul, H.A.R. 2017. Facies and stratigraphic architecture of the Kudat Formation, Sabah: Implications on provenance and Tectonics. Warta Geologi 43(3): 319-320.

Postma, G., Cartigny, M.J.B. \& Kleverlaan, K. 2009. Structureless, coarse-tail graded Bouma Ta formed by internal hydraulic jump of the turbidity current? Sedimentary Geology 219(1-4): 1-6.

Postma, G., Nemec, W. \& Kleinspehn, K. 1988. Large floating clasts in turbidites: A mechanism for their emplacement. Sedimentary Geology 58(1): 47-61.

Rangin, C., Bellon, H., Benard, F., Letouzey, J., Muller, C. \& Sanudin, T. 1990. Neogene arc-continent collision in Sabah, Northern Borneo (Malaysia). Tectonophysics 183: 305-319.

Rona, P. \& Seilacher, A. 2009. Paleodictyon nodosum: A living fossil on the deep-sea floor. Deep-Sea Research Part II: Topical Studies in Oceanography 56(19-20): 1700-1712.

Samira, G., Mohd, S., Nasiman, S. \& Mohammadsadegh, M. 2018. Sedimentary architecture and depositional environment of Kudat Formation, Sabah, Malaysia. In International
Conference on Architecture and Civil Engineering Series Materials Science and Engineering. Kuala Lumpur: Sigma Research and Consulting Sdn. Bhd. p. 012025.

Sanudin, T., Kong, V.S., Baba, M. \& Junaidi, A. 2017. Facies and sandstone characteristics of the Kudat Formation, Sabah, Malaysia. Geological Behavior 1(2): 20-25.

Seilacher, A. 2007. Trace Fossil Analysis. Berlin: Springer.

Shariff, A.K.O., Majeed, M.F. \& Sanudin, T. 1994. The Kudat ophiolite complex. Northern Sabah, Malaysia - field description and discussion. Bulletin of the Geological Society of Malaysia 20(5): 337-345.

Sohn, Y.K. 1997. On traction-carpet sedimentation. Journal of Sedimentary Research 67(3): 502-509.

Southard, J.B. 1991. Experimental determination of bed-form stability. Annual Review of Earth and Planetary Science 19: 423-455.

Stephens, E.A. 1956. The Geology and Mineral Resources of the Kota Belud and Kudat Area, North Borneo. Kuching: Malaysia Geological Survey Borneo Region Memoir.

Suggate, S.M. \& Hall, R. 2013. Using detrital garnet compositions to determine provenance; A new compositional database and procedure. The Geological Society 386(1): 373-393.

Taki, K. \& Parker, G. 2005. Transportational cyclic steps created by flow over an erodible bed. Part 1: Experiments. Journal of Hydraulic Research 43(5): 488-501.

Talling, P.J., Masson, D.G., Sumner, F.J. \& Malgesini, G. 2012. Subaqueous sediment density flows, depositional processes and deposit types. Sedimentology 59(7): 19372003.

Tinterri, R., Drago, M., Consomi, A., Davoli, G. \& Mutti, E. 2003. Modelling subaqueous bipartite sediment gravity flows on the basis of outcrop constraints: First results. Marine and Petroleum Geology 20(6-8): 911-933.

Tongkul, F. 2006. The structural style of Lower Miocene sedimentary rocks, Kudat Peninsula, Sabah. Bulletin of the Geological Society of Malaysia 49: 119-124.

Tongkul, F. 1994. The geology of Northern Sabah Malaysia: Its relationship to the opening of the South China Sea Basin. Tectonophysics 235(1-2): 131-137.

Tongkul, F. 1991. Tectonic evolution of Sabah, Malaysia. Journal of Southeast Asian Earth Sciences 6(3/4): 395-405.

Uchman, A. 2009. The Ophiomorpha rudis ichnosubfacies of the Nereites ichnofacies: characteristics and constraints. Palaeogeography Palaeoclimatology Palaeoecology 276(1): 107-119.

van Hattum, M.W.A., Hall, R., Pickard, A.L. \& Nichols, G.J. 2013. Provenance and geochronology of cenozoic sandstones of northern Borneo. Journal of Asian Earth Sciences 76: 266-282.

Walker, R.G. 1967. Turbidite sedimentary structures and their relationship to proximal and distal depositional environments. Journal of Sedimentary Research 37(1): 25-43.

Yagishita, K. 1994. Antidunes and traction-carpet deposits in deep-water channel sandstones, Cretaceous, British Columbia, Canada. Journal of Sedimentary Research 64(1a): 34-41. 
Hafzan Eva Mansor* \& Meor Hakif Amir Hassan Department of Geology

Faculty of Science

Universiti Malaya

Jalan Universiti

50603 Kuala Lumpur, Wilayah Persekutuan Malaysia

Hafzan Eva Mansor*

Department of Geoscience

Faculty of Earth Science

Universiti Malaysia Kelantan

17600 Jeli, Kelantan Darul Naim

Malaysia
Junaidi Asis

Geology Programme

Faculty of Science and Natural Resources

Universiti Malaysia Sabah

Jalan UMS

88400 Kota Kinabalu, Sabah

Malaysia

*Corresponding author; email: hafzan.eva@umk.edu.my

Received: 19 March 2020

Accepted: 2 August 2020 